\title{
COMPREENDENDO AS ESTRATÉGIAS DE APOIO ÀS FAMÍLIAS DE USUÁRIOS DO CAPS I MICRORREGIONAL DE LAURO MÜLLER - SC
}

DOI: http://dx.doi.org/10.18616/prat03

Juliana Daniel Rabelo

Curso de Psicologia - UNESC - Universidade do Extremo Sul Catarinense psicojulianadrabelo@gmail.com

\author{
Rosa Nadir Teixeira Jerônim \\ Psicóloga Comunitária - Autônoma \\ rntjpsi@gmail.com
}

Zolnei Vargas E. de Córdova UNESC - Universidade do Extremo Sul Catarinense zolneivargas@hotmail.com

Dipaula Minotto da Silva UNESC - Universidade do Extremo Sul Catarinense dms@unesc.net 


\section{INTRODUÇÃO}

A partir do movimento da Reforma Psiquiátrica brasileira, iniciada na década de 1970, as equipes de saúde mental passam a rever junto aos usuários e familiares o papel da família no processo de reabilitação psicossocial de sujeitos antes excluídos do convívio familiar e social. Os modelos de cuidado na perspectiva da reabilitação psicossocial a partir destas discussões, passaram a incluir o cuidador como uma relevância cada vez maior. Porém, verificam-se constantes dificuldades enfrentadas na prática do papel de cuidador, como reflexo das décadas de exclusão e segregação dos ditos loucos, que privilegiaram as internações de longa permanência à instrumentalização e amparo às famílias. Em contrapartida, sabe-se que o cuidado contribui para uma sobrecarga de familiares, podendo comprometer sua qualidade de vida. Estudos brasileiros e internacionais comprovaram que de forma geral, cuidadores de pessoas com condições crônicas e incapacitantes vivenciam algum tipo de sobrecarga (TUCKER et al., 1998; SENA 2008; PEGORARO, 2006 apud ALMEIDA, 2009).

Nessa ótica, o impacto do diagnóstico, a necessidade de se ajustar ao novo contexto, os encadeamentos da cronicidade do quadro clínico concomitante ao estigma social, podem gerar sofrimento, medo, angústia e culpa nos familiares. Isto porque, conforme a literatura, a família experiencia um quadro de desgaste o que, por sua vez, também pode influenciar na relação com a pessoa cuidada.

De modo geral, a presença de um sujeito com sofrimento psíquico dentro da família pode afetar seu funcionamento, sobretudo, suscita interrupção da rotina existencial do principal cuidador, na qual passa a colocar suas próprias necessidades e desejos em segundo plano, tornando-se sobrecarregado por incumbir com a responsabilidade gerada por esta patologia.

O interesse pelo tema deste trabalho manifestou-se a partir do estágio realizado na área da saúde mental. Durante a graduação, mais precisamente no segundo semestre de 2016, a pesquisadora participou enquanto acadê- 
mica do estágio supervisionado em Psicologia Social no Centro de Atenção Psicossocial (CAPS III) do município de Criciúma-SC. Esse estágio foi um importante momento por conta do contato com esse universo até então pouco conhecido, e para desconstruir preconceitos, refletindo sobre as possibilidades de reabilitação neste âmbito. Aos poucos foi possível conhecer o serviço de atendimento a sujeitos que apresentavam sofrimento psíquico, assim como também o cotidiano destes locais e os recursos terapêuticos disponibilizados aos mesmos.

Portanto, foi nesse mesmo cenário, na convivência com o CAPS, que alguns questionamentos surgiram, como: de que maneira seria para os seus familiares conviver com uma condição em que eles são, geralmente, os cuidadores? Que tipo de atenção é oferecido pelo CAPS a essas famílias? Que lugar a família ocupa no processo de reabilitação psicossocial desse sofredor psíquico?

Nesse sentido, houve o interesse em pesquisar sobre o tema para compreender a relação dos serviços com as famílias de usuários, posto que essa relação seja ponto fundamental e indispensável no âmbito da Reforma Psiquiátrica. $\mathrm{O}$ esforço de manter esse sujeito próximo à sua família, com o intuito principal de garantir o cuidado em liberdade, converteu-a numa legítima aliada no processo de reconstrução da identidade social da pessoa com transtorno mental (AMARANTE, 2001).

Para tanto, a escolha do local se deu após consulta à Câmara Técnica da RAPS da região carbonífera, onde se questionou que municípios teriam experiência exitosa de trabalho com família em CAPS. No ato da consulta a coordenação do serviço se colocou à disposição como campo para a realização da pesquisa.

Assim, considerando o CAPS o principal dispositivo na assistência em saúde mental, é importante compreender como este dispositivo vem efetivamente atuando, lançando luz na relação do trabalho que vem sendo desenvolvido com as famílias dos usuários. De acordo com a pesquisa de Mielke et al., intitulada "A inclusão da família na atenção psicossocial: uma reflexão", 
publicada em 2010, a inserção da família no CAPS é apontada como imprescindível para a concretização do processo de desinstitucionalização, ou seja, “a família é uma aliada, uma parceira no processo de reabilitação psicossocial do usuário" (p. 764).

Diante do exposto, considera-se relevante investigar de que maneira essas famílias são acompanhadas no Centro de Atenção Psicossocial (CAPS), visto que a atual política de saúde mental no Brasil respalda-se no retorno e na permanência da pessoa com sofrimento psíquico ao seu núcleo familiar e social. Além disso, verificou-se a incipiência de literaturas que abordem a temática do cuidado e inserção das famílias nos CAPS.

Objetivo geral: Investigar como são acompanhadas as famílias de pessoas com sofrimento psíquico que frequentam o Centro de Atenção Psicossocial (CAPS I) microrregional de Lauro Müller-SC, de acordo com proposta da Reforma Psiquiátrica brasileira. Objetivos específicos: Compreender quais são as estratégias de apoio às famílias dos usuários do CAPS; Conhecer a experiência de trabalho realizada em um grupo de família no CAPS; Analisar como o CAPS auxilia os familiares com base na proposta da Reforma Psiquiátrica brasileira.

\section{MÉTODOS}

O presente estudo é classificado como uma pesquisa exploratória, com um delineamento do tipo estudo de campo de abordagem qualitativa, escolhida por ser a mais adequada quando se trabalha com a subjetividade dos eventos e sujeitos.

De acordo com Michel (2015, p. 40), a pesquisa qualitativa se evidencia pelo fato de que "a verdade não se comprova numérica ou estatisticamente; ela surge na experimentação empírica, a partir da análise feita de forma detalhada, abrangente, consistente e coerente, e na argumentação lógica de ideias." A autora afirma, ainda, que neste tipo de pesquisa a realidade é investigada em seu ambiente natural, tentando dar significados aos fenômenos 
ou analisá-los conforme os sentidos atribuídos às pessoas envolvidas nesse contexto. Pinheiro et al. (2005 apud MICHEL, 2015) enfatiza:

A pesquisa qualitativa caracteriza-se por um estudo analítico, não necessariamente estatístico, cujo propósito é identificar e analisar com maior grau de profundidade dados e informações não mensuráveis, sentimentos, sensações, percepções, pensamentos, intenções, comportamentos passados, expectativas futuras, experiências, vivências. Para esse objeto de estudo, a pesquisa qualitativa se propõe a entender, interpretar motivos e significados de um grupo de pessoas em relação a uma questão especificamente determinada. (p. 41)

Nessa lógica, Tomasi e Yamamoto (1999, p. 22) corroboram ao dizerem que "a pesquisa qualitativa envolve a coleta e análise sistemática de materiais narrativos mais subjetivos [...]", fazendo uso, quando inevitável, de procedimentos onde é mínima a propensão de controle do pesquisador. Os autores enfatizam que os pesquisadores se direcionam a visibilizar "os aspectos dinâmicos, holísticos e individuais da experiência humana, tentando apreender tais aspectos em uma totalidade, no contexto daqueles que os estão vivenciando" (p. 24). Assim, esse modelo de pesquisa fundamenta-se na premissa de que somente se conhece o indivíduo a partir da narração da experiência humana, ou seja, da mesma maneira que é explicada pelo próprio sujeito.

No que tange a pesquisa exploratória, a mesma pretende "familiarizar-se com o fenômeno ou obter nova percepção do mesmo e descobrir novas ideias" (TOMASI; YAMAMOTO, 1999, p. 30). Desta forma, o estudo exploratório propõe um delineamento flexível para permitir que se considerem os inúmeros aspectos de um delimitado problema. Além disso, utiliza-se esse tipo de estudo para obter os elementos essenciais que lhe concedem encontrar os resultados que espera (TOMASI; YAMAMOTO, 1999).

Por fim, a pesquisa de campo configura-se na forma de coleta de dados do contexto natural, com o intuito de observar, criticar a realidade, alicerça- 
do na teoria estudada, no sentido de investigar de que maneira essa teoria reage na realidade. Desta forma, o confronto da teoria com a prática possibilitará responder ao problema da pesquisa e alcançar seus objetivos (MICHEL, 2015).

O local eleito para a coleta de dados foi o Centro de Atenção Psicossocial (CAPS I) microrregional dos municípios de Lauro Müller e Treviso, com sede em Lauro Müller. O município, que se situa ao sul do estado de Santa Catarina, possui uma população estimada de 15.149 mil habitantes de acordo com dados de 2017 do Instituto Brasileiro de Geografia e Estatística (IBGE). Treviso, igualmente localizado ao sul de Santa Catarina, possui população estimada de 3.863 pessoas (IBGE, 2017).

Os municípios atendidos pelo CAPS I em Lauro Müller pertencem à microrregião da Associação dos Municípios da Região Carbonífera (AMREC), logo recebem suporte da $20^{\text {a }}$ Gerência Regional de Saúde $\left(20^{\text {a }}\right.$ GERSA) da Secretaria Estadual de Saúde (SES) e compõem a Câmara Técnica da Rede de Atenção Psicossocial (RAPS) da região carbonífera.

O CAPS I foi inaugurado em 2014 e conta atualmente com 5 profissionais técnicos, possui um total de 124 usuários cadastrados e 65 usuários inseridos no serviço, e está instalado ao lado do Hospital Henrique Lage, no centro da cidade. A escolha do local se deu após consulta à Câmara Técnica da RAPS, onde se questionou que municípios teriam experiência exitosa de trabalho com família em CAPS. No ato da consulta a coordenação do serviço se colocou à disposição como campo para a realização da pesquisa.

Os sujeitos da pesquisa foram 2 familiares e 2 profissionais, sendo que a escolha desse número se deu considerando a logística da pesquisa, ou seja, por uma questão de organização, decorrente da distância do local, bem como ao tempo que a pesquisadora possuía para realizar o estudo. Além disso, no que concerne à pesquisa qualitativa, esta por sua vez não exige um número de sujeitos. Neste sentido, avaliou-se que a quantidade de sujeitos entrevistados não influenciou de forma negativa na qualidade do resultado da pesquisa. Contrariamente, os dados coletados foram ricos, colaborando significativamente para que se pudesse alcançar uma análise satisfatória. 
Sendo os sujeitos de pesquisa representados por 2 familiares e 2 profissionais, trata-se de moradores do município de Lauro Müller, do gênero feminino, com idades entre 31 e 60 anos, sendo que os dois familiares possuem ensino fundamental incompleto e são donas de casa; e os profissionais possuem ensino superior completo e atuam nesse CAPS de 2 anos a 4 anos. A formação inicial dos profissionais de ensino superior e outros dados não serão informados para garantia da identidade dos sujeitos.

Os critérios utilizados para a seleção dos entrevistados foram: apresentar disponibilidade para fornecer entrevista gravada, mediante sigilo de identificação e assinatura do Termo de Consentimento Livre e Esclarecido (TCLE); ser profissional do CAPS com no mínimo 1 ano de experiência na saúde mental; ser familiar e considerado, pela equipe do CAPS, como cuidador de usuário do CAPS.

Quanto ao termo "cuidador", compreende-se uma pessoa que presta cuidados a um usuário do CAPS, considerado como o responsável pelo usuário, ou seja, aquele a quem a equipe aciona em caso de necessidade.

Inicialmente foi realizado um primeiro contato com o CAPS, pela pesquisadora, para apresentar a proposta de estudo e, posteriormente, obter a Carta de Aceite para realização da pesquisa. Seguidamente, foi submetido o projeto ao Comitê de Ética em Pesquisa (CEP) da Universidade do Extremo Sul Catarinense - UNESC. Após aprovado, foi feito o contato com os participantes da pesquisa. O Termo de Consentimento Livre e Esclarecido (TCLE) foi apresentado para que autorizassem formalmente o estudo (Apêndice C).

A coleta de dados se deu em dois momentos, em que a observação participante no grupo de família ocorreu no período de abril a maio de 2018 e as entrevistas no período de junho a julho do ano corrente. $\mathrm{O}$ registro das observações foi feito através de anotações, compreendendo descrições do meio físico, atividades desenvolvidas, conversas, percepções, dentre outros, em diário de campo.

A observação participante pode ser vista como uma peça fundamental no estudo da pesquisa qualitativa. Diferentes estudiosos a utilizam como 
método de investigação para compreender a realidade (MINAYO, 2008). A autora ainda diz que a observação é:

[...] tratada como forma de complementar de compreensão da realidade empírica. Uma coisa é certa na opinião de todos os estudiosos: existe necessidade de o pesquisador relativizar o seu espaço social, aprendendo a se pôr no lugar do outro. No trabalho qualitativo, a proximidade com os interlocutores, longe de ser inconveniente, é uma virtude (p. 274).

Esse modelo presume que o pesquisador participe e insira-se à comunidade ou grupo estudado. Assim, nesse modo de observar, o pesquisador adquire confiança do grupo, favorecendo a aquisição dos dados (MICHEL, 2015). Seguiu-se a sugestão da forma tradicional, que propõe a utilização do instrumento chamado "diário de campo", um caderno onde o pesquisador registra o que é observado e que não é objeto de nenhuma parte da entrevista. Nesse diário devem ser anotadas todas as impressões pessoais, as conversas informais, as observações de comportamentos, entre outros aspectos, e esses dados devem ser utilizados para a análise do seu objeto de pesquisa (MINAYO, 2008).

As entrevistas foram orientadas por roteiros semiestruturados direcionados aos familiares e aos profissionais respectivamente (Apêndices A e B). Estas, por sua vez, ocorreram na sala de coordenação do CAPS I, tiveram duração aproximada de 40 minutos cada e foram gravadas em áudio. Os sujeitos da pesquisa foram escolhidos de acordo com a disponibilidade para ceder entrevistas, de forma aleatória. As entrevistas ocorreram durante o período de observação após aprovação do projeto pelo Comitê de Ética em Pesquisa (CEP).

Michel (2015), ao abordar sobre a modalidade de entrevista semiestruturada, refere que na mesma "o entrevistado tem liberdade para desenvolver cada situação em qualquer direção que considere adequada; permite explorar mais amplamente uma questão". A mesma autora destaca que: 
Os entrevistados são abordados com o mesmo número de perguntas, mas estas não são fechadas, podem ser explicadas, traduzidas. Ao longo do processo, perguntas podem ser retiradas por não fazerem sentido; outras podem ser oportunamente incluídas. O entrevistador conduz o processo, tem competência para alterar o roteiro, sem perder a essência do que quer abordar e cuidando de replicar o mesmo foco para as demais. (p. 87)

Desse modo, esse tipo de entrevista pode fazer emergir informações de forma mais livre e as respostas não estão condicionadas a uma padronização de alternativas.

Conforme as demandas do presente estudo, que visou investigar como são acompanhadas as famílias de pessoas com sofrimento psíquico que frequentam o CAPS I de Lauro Müller, a partir da Reforma Psiquiátrica brasileira, os dados desta pesquisa foram analisados por meio da análise de conteúdo. Sendo que para esta análise, primeiramente foi realizada a leitura flutuante das entrevistas transcritas, que consistiu na leitura exaustiva e organização do material de acordo com a representatividade e pertinência e, seguidamente, o material foi codificado com palavras-chave.

Desse modo, a análise de conteúdo configura-se em "uma técnica de levantamento de dados que utiliza textos, falas, informações já coletadas, de forma extensiva, ou seja, é uma análise feita a posteriori à coleta" (MICHEL, 2015, p. 87). De acordo com a autora, essa técnica busca elaborar uma análise profunda da mensagem, para investigar se existe ou não conformidade entre a realidade manifesta ou contida no texto, isto é, procura o que está oculto em cada mensagem. Além disso, foca na importância das respostas e na coerência dos dados fornecidos, bem como objetiva exteriorizar o que está encoberto.

Para aplicar a técnica de análise de conteúdo exige-se do pesquisador um nível de maturidade e responsabilidade, pois poderá suscitar conclusões precipitadas ou interpretadas incorretamente, gerando dados infundados para o alvo da pesquisa (MICHEL, 2015). 
Nessa ótica, por meio da análise de conteúdo, pode-se obter respostas para as questões apresentadas na pesquisa e, igualmente, pode-se confirmar as hipóteses (GOMES, 2004). O referido autor reforça que "o produto final da análise de uma pesquisa, por mais brilhante que seja, deve ser sempre encarado de forma provisória e aproximativa" (p. 79).

O projeto foi submetido à análise do Comitê de Ética em Pesquisa da Universidade do Extremo Sul Catarinense (UNESC) e aprovado sob o parecer n. 2.700.941 (Anexo A). Além disso, o estudo respeitou todas as diretrizes legislativas vigentes que tangem sobre os aspectos éticos em pesquisa que envolva seres humanos, seguindo os ditames das resoluções do Conselho Nacional de Saúde (CNS) n. 466/2012 e 510/2016.

As pessoas que aceitarem participar do estudo assinaram o Termo de Consentimento Livre e Esclarecido (TCLE), composto por duas vias, sendo que uma via ficou com o pesquisador e a outra fornecida ao participante, assim como receberam informações sobre os objetivos e a metodologia adotada. As entrevistas foram gravadas e posteriormente transcritas literalmente, depois foram analisadas de acordo com as etapas do método. As transcrições, os documentos (os dados) e as gravações ficarão de posse da pesquisadora durantes o prazo de cinco anos.

Quanto a possíveis conflitos de interesses, é importante citar que a pesquisadora proponente desta pesquisa não possui nenhum vínculo com o local de estudo.

Riscos: essa pesquisa não ofereceu riscos físicos e emocionais importantes a serem considerados. Entretanto, pela natureza interacional das entrevistas, tomou-se o cuidado, pois o processo de coleta de dados pode ocasionar o surgimento de emoções relacionadas às demandas da pesquisa. Em caso de suscitar emoções, os entrevistados poderiam contar com a pesquisadora para acolher os sujeitos em tais situações e a entrevista poderia ser interrompida a qualquer momento se o participante manifestasse interesse que assim ocorresse. Não foi necessária nenhuma interrupção ou intervenção durante a realização das entrevistas. 
Benefícios: ao aceitar fazer parte desta pesquisa, os envolvidos no processo ficaram cientes que sua participação colaborou para uma pesquisa científica referida a um Trabalho de Conclusão do Curso de Psicologia. Além disso, a pesquisa possibilitou visibilizar as estratégias que são utilizadas para dar suporte às famílias de usuários frequentadores de um CAPS de referência na região, com possibilidade de expansão deste conhecimento a partir de produção/publicação científica. O material das entrevistas foi arquivado pela pesquisadora para que se guarde o sigilo das informações. Neste caso, para garantir seu anonimato, os nomes dos entrevistados foram substituídos na pesquisa por códigos de identificação utilizando a letra inicial do segmento ao qual pertence e a numeração de acordo com a ordem da realização das entrevistas por segmento de sujeito. Desse modo, as entrevistas foram referenciadas da seguinte forma: EF1 e EF2 (entrevistas dos familiares e número conforme a ordem de realização); EP1 e EP2 (entrevistas dos profissionais e número conforme a ordem de realização).

\section{RESULTADOS}

Os resultados apresentados têm como base os dados coletados em dois momentos: um deles a partir das entrevistas com familiares e profissionais, e outro a partir da observação no grupo de família.

Com vistas a responder aos objetivos da pesquisa, os resultados serão apresentados a partir de 3 eixos, sendo eles: as compreensões sobre as principais estratégias de apoio às famílias; a identificação de experiências realizadas no grupo de família; e a análise de como o CAPS auxilia os familiares a partir da Reforma Psiquiátrica brasileira. 


\section{ESTRATÉGIAS DE APOIO ÀS FAMÍLIAS DE USUÁRIOS DO CAPS I DE LAURO MÜLLER}

De acordo com o estudo teórico, a família sempre foi afastada dos cuidados da pessoa com sofrimento psíquico, tanto pelo difícil acesso aos hospitais psiquiátricos, quanto pela responsabilização/culpabilização das famílias no adoecimento da pessoa com sofrimento psíquico. No entanto, com as significativas transformações ocorridas a partir da Reforma Psiquiátrica brasileira, constitui-se um modelo para a atenção em saúde mental, direcionada pela ideia de desinstitucionalização (CAMATTA et al., 2011).

Os autores supracitados referem que no contexto de ação em saúde mental surgem como um dos recursos e configurações de intervenções os CAPS. Estes se constituem como a principal estratégia no processo da Reforma Psiquiátrica, como dispositivos designados a acolher as pessoas que apresentam sofrimento psíquico, instigando sua inserção social e familiar, do mesmo modo que corroborando no desenvolvimento da sua autonomia (MINAS GERAIS, 2007 apud FACURY, 2010).

Nesse bojo, uma das mudanças promovidas com a reelaboração da assistência em saúde mental, foi a de viabilizar que o sujeito com sofrimento psíquico continue com sua família. Todavia, para que este convívio seja favorável, é necessário que o serviço esteja inserido numa rede articulada de apoio e de organizações que se coloquem a disponibilizar uma continuidade de cuidados (SCHRANK, 2006).

Nesse sentido, verificou-se a partir das narrativas de familiares, que uma significativa ação de suporte aos familiares é compreendida pela existência do CAPS. Essa questão surge como um benefício aos familiares, ao mostrar que se "tem o serviço e ficar com o usuário", permitindo que o familiar "descanse" em alguns momentos, ou, em outras palavras, que o familiar tem uma espécie de auxílio que possibilita a diminuição da sobrecarga dos familiares. Assim, essa ação revela-se nos relatos a seguir: 
[...] nossa, ela fica em casa uma vez na semana, na quinta-feira em casa. Imagina nós assim né, se não tem CAPS. Ela mesma assim, se não tem CAPS fica toda agoniada, bem...então ela já tem aquele, como diz, uma família né (EF1).

[...] Porque a gente vê as atitudes dele, normalmente ele chega mais calmo sabe, bem mais calmo. Aquele dia fica muito melhor de tu trabalhar com ele, porque (o usuário) é um pouquinho difícil, por 3 motivos que eu te dou sobre (o usuário): um, eu sou (grau de parentesco), a idade e a doença (EF2).

Mediante os escritos acima, avalia-se que os familiares retratam que quando o serviço fica com o usuário está fazendo algo pelo familiar. Ou seja, atender os usuários no CAPS é uma maneira de conceder assistência a essas famílias, caracterizado, principalmente, por garantir um lugar de vida, que as famílias expressam ao dar ênfase e o fato de que os usuários podem passar o dia, que se sobrepõe ao fato de ter o atendimento em si (consultas, medicações entre outros recursos terapêuticos).

A literatura vai apontar sobre o papel dos profissionais de saúde sobre seu impacto na questão da sobrecarga carga familiar no campo da saúde mental da seguinte forma:

O conhecimento desse quadro de sobrecarga por parte dos profissionais de saúde sugere que as intervenções terapêuticas levem em consideração essa realidade. Ajudar os familiares na interação e na gestão da vida cotidiana dos pacientes alivia o peso dos encargos, facilita o processo de estabelecimento de uma cooperação, diminui os fatores estressantes ativadores de situações de crise, estimula a criação de possibilidades participativas, melhorando a qualidade de vida de todas as pessoas envolvidas (MELMAN, 2008 apud SANTIN; KLAFKE, 2011, p. 155). 
Conforme as entrevistas com os profissionais, para atenuar a sobrecarga dos familiares é preciso trabalhar numa rede de cuidados, onde o usuário é atendido de maneira integral, não permitindo que este fique somente sob a responsabilidade da família ou do CAPS. Neste sentido, um dos profissionais corrobora os benefícios do CAPS às famílias ao inserir o usuário do serviço, ao afirmar que:

[...] A gente conseguiu atrair mais pessoas né e os familiares também, eles gostam muito do serviço, porque é um serviço que tem o ano todo né, um serviço que auxilia muito quem tem uma pessoa com transtorno mental em casa. A gente tá o ano todo trabalhando, a gente não fecha, só final de semana (EP2)

Ainda de acordo com os dados levantados, os profissionais enfatizam outras formas de auxílio às famílias de pessoas com sofrimento psíquico no CAPS em questão. Dentre elas, podem ser citadas: visita domiciliar, a busca ativa, $\mathrm{o}$ atendimento individual e $\mathrm{o}$ acolhimento.

A visita domiciliar é compreendida como "uma opção para o cuidado da rede familiar, justificando que o território de atuação do CAPS vai além do contexto deste, com um referencial de que o cuidado integral só ocorre a partir do conhecimento do contexto do sujeito" (TELES; BOMFIM; QUEIROZ, 2016, p. 13).

Ao abordar as visitas domiciliares, os profissionais consideram-nas como um importante recurso terapêutico. Isso fica claro nos relatos abaixo:

[...] nas atividades no domicílio, elas têm sido um nicho muito importante pra nós nesse sentido, de a gente realmente resgatar esse contexto social que muitas vezes foi perdido ou talvez nunca aprenderam a fazer [...]. A gente começou agora semana passada um trabalho de referência de atividades domiciliares que são as AVDs (Atividades de Vida Domiciliar) junto com a família e paciente, e a gente 
viu que havia situações que a família ou o familiar que às vezes é o responsável, que é o curador, está mais doente que o paciente, ele é tão paciente quanto o que nós temos aqui (EP1).

E a visita domiciliar, visita e atendimento, que a gente visita, também entra, senta e conversa né e faz a intervenção. Eu acho que no momento é a melhor estratégia que a gente tá utilizando, ir até essas famílias, eu vejo isso, eu particularmente tô gostando muito de fazer as visitas, é muito esclarecedor pra gente [...] quanto mais contato a gente tiver com a realidade dessa pessoa, a família em que ele vive, a casa onde ele mora, como é que são seus hábitos né, a sua rotina, acho que melhor vai ser o plano de tratamento dele (EP2).

Esses depoimentos demonstram que a visita domiciliar é um recurso indispensável para o amparo em saúde, visto que por meio dela os profissionais podem apoiar e cuidar não unicamente o usuário, porém, da mesma forma a família, fortalecendo a prática de enxergar o sujeito integralizado. É mediante as visitas que se torna viável intervir conhecendo a rotina do usuário, do familiar e o meio em que estão inseridos, possibilitando identificar as reais necessidades.

As ideias de Teles, Bomfim e Queiroz (2016, p. 13) sugerem que "a casa não é só um lugar físico, é um local de relações e experiências para os que nela convivem, devendo, portanto, as relações e os acontecimentos deste serviço também se estenderem ao domicílio".

No que tange a busca ativa, esta exprime:

[...] um sentido de comprometimento e responsabilidade conjunta da equipe. É um modo de estar com a família quando as mesmas se apresentarem distantes do tratamento, ou com dificuldades no cuidado ou até mesmo quando a família não consegue conciliar seu horário com 
o do funcionamento do CAPS. Possibilita um outro espaço de expressar compromisso, de acolhimento das necessidades e dificuldades, ultrapassando a estrutura física das práticas assistenciais (SCHRANK, 2006, p. 86).

Os resultados apontaram para a necessidade de estar buscando novas práticas. Assim sendo, a equipe demonstra capacidade de invenção a partir das características dos familiares do município:

Alguns familiares, nós temos um distanciamento muito grande né, do tratamento do paciente, alguns a gente não consegue entrar em contato, a gente tem que ficar indo atrás sempre buscando contato, outros estão sempre aqui, até porque tem dificuldades de lidar com eles (usuários), então buscam muito a nossa ajuda, a nossa orientação. Então tem os dois lados assim, aqueles que buscam bastante o serviço, [...] e aqueles que nunca aparecem e a gente tem que tá indo atrás. E que nós, profissionais de saúde $n e ́$, às vezes a gente [...] trabalha atendendo uma demanda que vem espontaneamente ou encaminhada, que vem até nós, e eu acho que um grande aprendizado que a gente tá tendo é que nós temos que ir em busca das pessoas né, então hoje a gente faz mais esse movimento. A gente vai, faz visita domiciliar né, a gente faz contato telefônico com mais frequência. Antes a gente marcava os grupos, marcava as reuniões e esperávamos que eles viessem [...] (EP2).

A busca ativa proporciona um deslocamento da equipe para além do CAPS, assim conhecendo a realidade das famílias e usuários. Nesse sentido, a busca ativa é utilizada para "denotar uma postura política de trabalho sob a bandeira da integralidade do cuidado, que pressupõe atender às necessidades de saúde para além da demanda espontânea” (MATTOS, 2001 apud LEMKE; SILVA, 2010, p. 286).

Dentre as diversas formas de apoio aos familiares no CAPS, surge também nas narrativas o atendimento individualizado. Este proporciona aos 
sujeitos implicados uma comunicação mais direta e precisa, permitindo um diálogo mais próximo sobre as dificuldades encontradas pelos profissionais, ou familiares e usuários. Assim, quando no momento exige entender alguma conduta, questionar qualquer conjuntura que envolve uma pessoalidade, ou quando o indivíduo necessita de orientações, é sugerido o atendimento individual (SCHRANK, 2006).

No CAPS I de Lauro Müller, o atendimento individual é ofertado aos usuários e familiares com a finalidade de orientar, dar suporte, assim como acompanhar seu tratamento. É, também, através do atendimento individual que o profissional verifica as necessidades do usuário e poderá encaminhá-lo a integrar-se em um grupo. Assim, os profissionais trazem em suas falas:

[...] eu acho que ele traz no grupo, traz pro grupo, mas também traz de forma individualizada as dificuldades que ele tem, e com base nas dificuldades apresentadas a gente vai fazer as orientações pertinentes (EP1).

$O$ atendimento individual, onde a gente conversa individualmente com cada familiar, a gente entra realmente especificamente naquele caso né [...] (EP2).

Nessa ótica, as atividades de inclusão da família no contexto da saúde mental também são exercidas no atendimento individualizado, e este também tem como intuito conceder amparo emocional, discutir intervenções, assim como estabelecer laços afetivos. Assim, Mielke (2010) enfatiza que compreendendo a família como integrante essencial no processo de reabilitação, essa deve ser acompanhada pelos serviços de saúde mental de modo que suas necessidades sejam acolhidas.

Nessa mesma linha de compreensão, considera-se o acolhimento como uma das estratégias de apoio, entendido como: 
[...] acolher significa repensar a organização do processo de trabalho dos serviços substitutivos, que trabalham sob a lógica da atenção psicossocial. Para a prática do acolhimento é imprescindível que a equipe de saúde compreenda a importância dessa estratégia para a reabilitação da família, o objeto do cuidado, compreendendo que as tecnologias relacionais são importantes para a produção do cuidado na atenção psicossocial. [...] Nesse sentido, sinceridade, cumplicidade, afetividade, confiança e responsabilização são instrumentos do trabalho em saúde efetivos na acolhida, promovendo o fortalecimento e apoio nas relações com os familiares (MIELKE, 2010, p. 763).

Na atenção psicossocial, o acolhimento e a escuta são instrumentos primordiais de trabalho. São eles que viabilizam dar voz ao sofrimento do sujeito e, portanto, uma escuta qualificada faz toda diferença. É através da escuta que o indivíduo, ao falar para o outro, possibilita o alívio e a reflexão acerca da sua condição, consequentemente, minimizando a dificuldade e escolhendo o que é melhor para si (MIELKE, 2010).

Muito bom, tanto como elas como psicóloga, como psiquiatra, como a coordenadora, a enfermeira, todos são muito atenciosos sabe, eu acho assim que a atenção tanto pra eles que são doentes como pra nós é essencial sabe, porque se tu te sentes acolhida, todo mundo se sente acolhido, né? (EF2).

Partindo da narrativa do participante, mostrou-se o envolvimento da equipe na escuta às necessidades do usuário e dos familiares, evidenciando, assim, a acolhida do CAPS. O acolhimento é visto como uma ação em saúde da qual o resultado é evidente, já que as famílias estabelecem vínculos afetivos significativos com os profissionais do serviço, tendo-os como referência para o cuidado. 
Neste sentido, compreende-se que o acolhimento não representa a completa solução dos problemas expostos pelo paciente, mas uma atenção concedida abrangendo a escuta, a valorização das queixas, o reconhecimento das necessidades e um direcionamento adequado das demandas (SCHRANK, 2006).

A visita domiciliar, a busca ativa, o atendimento individual e o acolhimento foram analisados nos discursos de profissionais e familiares como importantes estratégias de cuidado as famílias dos usuários. Estas se mostram como ferramentas importantes de integração para a parceria entre a família e o serviço. Entretanto, o grupo de família apareceu na pesquisa como a principal estratégia de atenção dirigida à família, bem como de grande influência para operacionalização dos demais processos. Empiricamente já se sabia que a equipe considerava o grupo uma prática exitosa, neste sentido, buscou-se conhecer a experiência de trabalho realizada no grupo.

\section{A EXPERIÊNCIA DO GRUPO DE FAMÍLIA DO CAPS I DE LAURO MÜLLER}

Para dar início a esse capítulo, considera-se importante destacar a definição de grupo. Zimerman (2000), ao abordar os grupos, refere que "um conjunto de pessoas constitui um grupo, um conjunto de grupos e sua relação com os respectivos subgrupos se constitui em uma comunidade, e um conjunto interativo das comunidades configura uma sociedade". (p. 82)

$\mathrm{O}$ autor supracitado assinala que as pessoas convivem e interagem na maior parte de seu tempo em diversos grupos. Entretanto, quando várias pessoas se encontram num mesmo espaço, é designado um agrupamento. Assim, para que se constitua um grupo, é preciso que as pessoas tenham interesses em comum, isto é, devem se unir em volta de um propósito comum.

No contexto do CAPS I de Lauro Müller, os encontros do grupo de família ocorrem mensalmente, sempre na última quarta-feira a partir das 
19:00 horas. Os familiares possuem um cronograma anual dos encontros, e caso haja algum imprevisto, as famílias são avisadas previamente. Ademais, o grupo acontece à noite por conta de que a maioria das famílias trabalha facilitando o acesso, e disponibiliza o transporte para os que não têm condições de vir.

Ao investigar as principais estratégias de apoio às famílias de usuários do CAPS I de Lauro Müller, os familiares apontaram o grupo de família como a principal estratégia direcionada exclusivamente a eles ofertada pelo serviço. Isso é exposto nas seguintes falas:

Ela (usuária) vem todos os dias, ela só folga na quinta-feira, então assim, tem várias atividades e daí não sei te dizer. E pra gente no momento não, a gente vem uma vez no mês na reunião do grupo [...]. O que eu participo, assim, é da reunião, de vez em quando eu venho aqui buscar algum papel, e na minha opinião tá bom, pra mim não tenho nem o que reclamar (EF1).

Participam de cada encontro uma média 25 a 30 familiares e o transporte destes é ofertado pelo CAPS, pois esta é a única forma de acesso ao serviço aos que não possuem transporte próprio, uma vez que não há transporte coletivo na localidade. No dia da observação estavam presentes 10 familiares, que não dependiam do transporte do serviço, pois o carro do CAPS estava quebrado desde novembro de 2017. Nesse sentido, verificou-se que a questão do transporte aparece como um desafio para o serviço, uma vez que afeta diretamente a participação de muitos familiares nos encontros do grupo.

A participação no encontro possibilitou identificar que o grupo é organizado por profissionais (coordenadora/assistente social, psicóloga e enfermeira), onde inicialmente ocorre a acolhida aos participantes. Na sequência, há a leitura da pauta da noite que em geral aborda o reordenamento da proposta terapêutica dos pacientes, ou seja, o que o serviço está trabalhando com o paciente no CAPS e o que os familiares podem fazer como extensão 
em suas casas, e outros assuntos, de acordo com as necessidades da equipe e do grupo.

Dessa forma, chama a atenção a pauta "projeto terapêutico", por meio de conhecer a família, conhecer a casa, como o paciente vive; pois, nem sempre o que é trazido pela família é a realidade que se apresenta. O que pode ser também observado na narrativa do familiar:

Assim, antes ela vinha três dias na semana, depois foi aumentado pra quatro, e nós participamos da decisão de ela vir mais. A (profissional) falou na reunião, até, assim, pra nós foi [...] bom, pois como ela gosta de vim aí é um desenvolvimento pra ela, porque se ela tá em casa aí ela fuma muito (EF1).

Nessa lógica, a discussão do projeto terapêutico junto aos familiares surge como um diferencial nessa experiência de grupo. Segundo Boccardo et al. (2011), o projeto terapêutico é entendido como "uma estratégia de cuidado organizada por meio de ações articuladas desenvolvidas por uma equipe multidisciplinar" (p. 87), sendo estabelecida com base na particularidade do indivíduo, tendo em vista suas necessidades e o contexto social o qual está inserido. Os referidos autores enfatizam que o propósito último das ações de cuidado é o resgate da cidadania, sendo que este resgate somente pode ser atingido através da singularização do projeto terapêutico.

Identificou-se que o grupo tem como um dos objetivos, ser espaço de comunicação entre equipe e familiares, onde se esclarecem procedimentos e mudanças na rotina do serviço. De acordo com o registro do diário de campo:

Assim, a coordenadora explicou aos familiares que a visita domiciliar é um instrumento que a equipe do CAPS utiliza para conhecer a realidade do paciente, bem como não tem o intuito de cobrar ou fiscalizar, mas é uma forma de entender o que está acontecendo e trabalhar junto da família determinadas atividades para potencializar a 
autonomia de cada usuário, ou seja, melhorar o ambiente em que o paciente está inserido (DIÁRIO DE CAMPO DE OBSERVAÇÃO, LAURO MÜLLER, 2018).

Por esse ângulo, a equipe demonstrou aos familiares que por meio das Atividades de Vida Domiciliar (AVD), é possível desenvolver práticas não apenas no serviço, mas que é importante se estender até o domicílio, fortificando, assim, o papel das visitas domiciliares.

Verificou-se que os profissionais fazem uma sensibilização com os familiares sobre a reconstrução da autonomia dos pacientes, uma vez que ressaltam que os mesmos não são incapazes, mas que precisam de estímulo para a realização das atividades, porque também, muitas vezes, a família faz por ele. Sendo assim, ficou evidente que, nas atividades de grupo, um dos propósitos é promover a autonomia, mesmo nas atividades mais simples, partindo do ponto de que cada um irá fazer dentro de sua limitação, porque os usuários têm condições e são capazes. Visto também que muitas vezes, pela sua condição, o usuário é incapacitado e seu transtorno potencializado.

$\mathrm{O}$ atendimento no CAPS possui, entre outras, a finalidade de minimizar as dificuldades no convívio social e a de ampliar as possibilidades do usuário em conduzir sua própria vida, tendo por horizonte a inserção social e a promoção de autonomia do usuário (CAMATTA et al., 2011, p. 4410).

A promoção da autonomia dos usuários como foco das ações do CAPS aparece como uma demanda da equipe, solicitando o apoio dos familiares. $\mathrm{O}$ foco das ações nesse contexto é de potencializar a reabilitação psicossocial dos usuários do serviço, que se refere a "um processo de reconstrução, em exercício pleno da cidadania, e, também, de plena contratualidade nos três grandes cenários: habitat, rede social e trabalho com valor social" (SARACENO, 2016, p. 22). O mesmo autor ainda diz que a reabilitação psi- 
cossocial é apontada como uma indispensabilidade e obrigação ética e deve incumbir aos profissionais que dispõem de uma abordagem ética no campo da saúde mental. Pitta (2016) reforça que a reabilitação psicossocial é um meio de possibilitar ao usuário recuperar um nível maior de autonomia no desempenho de suas funções na comunidade.

Verificou-se que a questão da medicação também é contemplada no grupo de família, onde se orienta sobre os remédios dos pacientes, assim como os informa sobre algumas mudanças na sua prescrição. Além disso, é destacada a importância que a família tem no tratamento de cada paciente, que precisa ouvir, observar, perceber aquilo que está fora do "normal", podendo trazer para a equipe.

De acordo com Pontes (2009 apud SANTIN; KLAFKE, 2011):

[...] nos grupos de familiares ou nos atendimentos de família, é comum que as discussões girem em torno dos sintomas, e é importante que o profissional que coordena o grupo fique atento às possibilidades e ao conjunto de recursos que a família apresenta e como cada um se apropria deles ou como fica paralisado diante do momento vivido. (p. 151)

Além disso, os profissionais percebem que muitas vezes o usuário não consegue ler o nome no rótulo, mas que podem alcançar "o comprimido em cima da mesa, o copo de água e engolir”. Desta maneira a equipe coloca os familiares a pensarem sobre a potencialização da autonomia em relação à administração da medicação. No entanto percebeu-se, uma certa cobrança para a autonomia.

É no grupo de família que profissionais dividem com as famílias sobre o desenvolvimento da autonomia do usuário, e citam nesse dia, por exemplo, como os pacientes gostam das oficinas de artesanato e culinária e que é justamente através dessas oficinas que trabalham o resgate de algumas tarefas básicas na cozinha, como: bater um bolo, lavar a louça, secar a louça ou 
guardar, organizar, etc. Assim, são nesses grupos que trabalham com algumas técnicas como as noções de higiene, de manipulação dos alimentos, as questões do lixo, mas sempre dentro da capacidade de cada um dos pacientes, sendo eles supervisionados e orientados pelos técnicos.

O relato acima mostra como é forte nas reuniões a questão da relação família-serviço no que diz respeito à construção da autonomia do usuário. É essa proposta de autonomia na perspectiva da desinstitucionalização, entendendo que o sujeito pode voltar para uma vida em sociedade. Assim, cabe aqui ilustrar com a fábula citada por Paulo Amarante na sua obra $O$ homeme a serpente:

Uma fábula oriental conta a história de um homem em cuja boca, enquanto ela dormia, entrou uma serpente. A serpente chegou ao seu estômago, onde se alojou e onde passou a impor ao homem a sua vontade, privando-o assim da liberdade. O homem estava à mercê da serpente: já não se pertencia. Até que uma manhã o homem sente que a serpente havia partido e que era livre de novo. Então dá-se conta de que não sabe o que fazer da sua liberdade: 'No longo período de domínio absoluto da serpente, ele se habituara de tal maneira a submeter à vontade dela a sua vontade, aos desejos dela os seus desejos e aos impulsos dela os seus impulsos, que havia perdido a capacidade de desejar, de tender para qualquer coisa e de agir autonomamente.' 'Em vez de liberdade ele encontrara o vazio', porque 'junto com a serpente saíra a sua nova essência, adquirida no cativeiro', e não lhe restava mais do que reconquistar pouco a pouco o antigo conteúdo humano de sua vida (BASAGLIA, 1981 apud AMARANTE, 2003, p. 66).

Nessa lógica, a autonomia é vista como o oposto da institucionalização e que os usuários precisam da reabilitação psicossocial como estratégia de desinstitucionalização. Sendo que "o processo de desinstitucionalização demonstra tornar-se possível construir e inventar novas perspectivas de vida e 
subjetividade para aqueles mesmos sujeitos, e não apenas 'evoluções' e 'prognósticos' da doença mental" (AMARANTE, 2003, p. 31).

Assim sendo, verificou-se que a equipe está redirecionando o trabalho no âmbito da família, visto que é nesse contexto que, por exemplo, o usuário é visto como alguém que pode, entre outras coisas, organizar o seu quarto, a sua medicação, a sua roupa. Então a família precisa compreender esse processo para ajudar os usuários no desenvolvimento de suas habilidades, que vai na contramão da tutela que antes era lhes ensinada. Pontuou-se que os usuários, muitas vezes, ao fazer uma atividade fora do espaço do CAPS, mesmo sendo proposta pela equipe, não conseguem. Portanto, o trabalho no domicílio vem de encontro com isso, ajudando a potencializar e identificar o que está levando ele a não conseguir fazer tais atividades por exemplo. Nesse sentido, essas ações refletem o foco na reabilitação para as atividades cotidianas.

Identificou-se que existem muitas famílias em situações de vulnerabilidade socioeconômica. A equipe esclarece que para dar suporte a estas famílias existe uma rede de serviço de assistência que se pode estar articulando. Pois, por exemplo, como é possível trabalhar a questão do banho se na casa o esgoto está a céu aberto? Assim, durante uma visita é importante ver o contexto e a pessoa no seu integral.

Também é no contexto do grupo que a equipe aborda sobre a questão da sobrecarga, e destacam que:

Constantemente, a família se mostra cansada, mas que conseguem compreender isso, não significando que a família está negligenciando ou não quer cuidar, mas que isso poderá aparecer, uma vez que até para uma equipe capacitada torna-se exaustivo. Nesse sentido, conseguem observar através das visitas que a família está mais doente que o paciente, que a familia está fragilizada tanto quanto ou até mais que o a paciente. Mas que o paciente está medicado, é atendido no CAPS, recebe cuidados no serviço e em casa, e questionou-se "mas quem cuida dessa família?" Os profissionais percebem na fala dos cuidadores um "pedido de socorro", no sentido de "olha pra mim que eu também estou 
precisando de ajuda, me cuida!" (DIÁRIO DE CAMPO DE OBSERVAÇÃO, LAURO MÜLLER, 2018).

Assim, a sobrecarga familiar é compreendida por (MELMAN, 2001 apud SCHRANK, 2006, p. 44) como forma de "definir os encargos econômicos, físicos e emocionais a que os familiares estão submetidos e o quanto a convivência com um paciente representa um peso material, subjetivo, organizativo e social".

Essa sobrecarga é manifestada por um familiar no momento em que os profissionais a questionam sobre a possibilidade do usuário (seu familiar) vir mais um dia no CAPS:

Se tu colocares pra mim eu dou graças a Deus! Porque é cansativo, porque eu fico com ele sozinha o dia todo e tem horas que dá vontade de sair correndo, e eu não tenho final de semana e faz 5 anos que eu cuido dele [...] (FAMILIAR DO GRUPO - DIÁRIO DE CAMPO DE OBSERVAÇÃO, LAURO MÜLLER, 2018).

Nesse sentido, o grupo tem por objetivo conceder apoio aos familiares, "tanto no sentido de ser um espaço para tirar dúvidas sobre o tratamento e o manejo com o usuário, como um espaço para que o familiar cuidador possa desabafar, falar das suas angústias e do seu cansaço" (TELES; BOMFIM; QUEIROZ, 2016, p. 3).

Pôde-se perceber que, por meio do acolhimento no grupo, foi possível gerar um ambiente de confiança que oportunizasse aos familiares falar, conversar, exteriorizar seus sentimentos e dúvidas referentes ao sofrimento psíquico do seu familiar usuário. A equipe trabalhou com a família de forma divertida e com muito respeito, deixando os familiares bem à vontade e trouxe a eles informações pertinentes sobre seu familiar. Nessa ótica, mediante a confiança: 
O integrante compartilha suas vivências no grupo e o coordenador ao exercer a escuta, fornece as orientações voltadas aos sentimentos e inquietações dos familiares, frente às dificuldades que se apresentam. Há o desencadeamento de um processo sucessivo de revelações quanto às potencialidades, como também, os limites do grupo, refletindo na satisfação do familiar com a prática assistencial (RIBEIRO; COIMBRA; BORGES, 2012, p. 378).

No decorrer do grupo foram tratados diferentes assuntos, esclarecimentos e escutas dos familiares. Verificou-se que o encontro foi um momento de cuidado para estas famílias que também têm a necessidade de serem ouvidas e cuidadas, pois são elas que convivem com as pessoas que tem transtorno mental, fazendo com que elas também sofram com a situação do seu familiar.

O grupo coloca-se na qualidade de continente à medida que as angústias dos integrantes são identificadas e trabalhadas, e não apenas escutadas. Dessa forma, os participantes sentem que possuem um ponto de apoio, ao qual eles recorrem sempre que necessário (RIBEIRO; COIMBRA; BORGES, 2012, p. 381).

Ao longo do grupo também foi possível sentir os familiares mais atuantes, partilhando suas experiências aos demais do grupo. Portanto, ficou evidente que aquele momento tinha sido um momento além da troca de informações, no qual os familiares puderam se sentir à vontade para perguntar ou compartilhar algo e que também puderam aprender mais sobre o sofrimento psíquico do seu familiar usuário, tendo assim o grupo como um apoio familiar.

Finalmente, compreendeu-se que o grupo de família vai além da troca de experiências, uma vez que viabiliza que os familiares se sintam suavizados ao perceberem que seu problema também é enfrentado por outros familiares. Para Melman (2006 apud RIBEIRO; COIMBRA; BORGES, 2012), 
"o processo de identificação facilita aos participantes ver no outro o reflexo de sua própria realidade, aliviando a sensação de isolamento e solidão”. (p. 380)

Assim, com base na observação e nas entrevistas em confronto com a literatura, percebeu-se que o grupo é o espaço dinamizador de todas as ações de cuidado na interlocução entre familiares e profissionais. Para tanto, o CAPS apresenta algumas formas para expressar os modos de apoio às famílias dos usuários do CAPS I de Lauro Müller, sendo elas apresentadas no eixo a seguir.

\section{ANÁLISE DAS ESTRATÉGIAS DE APOIO DO CAPS I MICRORREGIONAL DE LAURO MÜLLER, NA PERSPECTIVA DA REFORMA PSIQUIÁTRICA BRASILEIRA}

A Reforma Psiquiátrica tem vivido um enorme desafio enquanto proposta de reorientar a assistência em saúde mental no Brasil, consolidando-se com inúmeros embates e obstáculos. Porém, com a efetivação das redes de atenção em saúde mental, onde os CAPS são dispositivos centrais nessas redes, tem-se revelado que esta é uma via possível quando articulada por meio de diferentes práticas sociais, nas quais integram equipe, usuário, família e sociedade (SCHRANK, 2006).

Nesse sentido, as políticas de saúde mental vigentes vêm desde a década de 1990 estimulando a constituição de uma rede de saúde mental nos estados e municípios com a implantação de serviços substitutivos ao hospital psiquiátrico. Ou seja, estimulando o atendimento das pessoas em sofrimento psíquico o mais próximo da sua residência, em serviços funcionando em regime de "portas abertas" na comunidade, conduzindo suas ações terapêuticas para a promoção da reabilitação psicossocial dessas pessoas, sem romper os laços sociais entre elas e suas famílias e a comunidade (TELES; BOMFIM; QUEIROZ, 2016, p. 8). 
Nessa ótica, a família torna-se personagem essencial nos processos de reabilitação dos usuários, envolvendo-se nos cuidados de seus familiares. Por outro lado, a prática profissional em assistência em saúde deve-se pautar na observação das dificuldades e cuidados de maneira integral.

Considerando o valor da implicação da família no cuidado às pessoas em sofrimento psíquico e da necessidade de apoio das equipes para os familiares dessas pessoas, mostra-se importante analisar os modos de apoio aos familiares identificados no CAPS, relacionando-os à Reforma Psiquiátrica brasileira.

Para tanto, se faz importante compreender que a política de saúde mental com base na Reforma Psiquiátrica brasileira se dá com o objetivo de ofertar cuidados na lógica da desinstitucionalização. Rotelli, Leonardis e Mauri (2001) afirmam que:

[...] a desinstitucionalização é um trabalho prático de transformação que, a começar pelo manicômio, desmonta a solução institucional existente para desmontar (e remontar) o problema. Concretamente se transformam os modos nos quais as pessoas são tratadas (ou não tratadas) para transformar o seu sofrimento, porque a terapia não é mais entendida como perseguição da solução-cura, mas como um conjunto complexo, e também cotidiano e elementar, de estratégias indiretas e mediatas que enfrentam o problema em questão através de um percurso crítico sobre os modos de ser do próprio tratamento. [...] A ênfase não é mais colocada no processo de "cura", mas no projeto de "invenção de saúde" e de "reprodução social do paciente" (p. 29-30).

O CAPS I de Lauro Müller mostra-se potente nas ações de desinstitucionalização ao contemplar as seguintes questões: abertura às famílias; redução das internações; apoio do desenvolvimento da autonomia para a reinserção social (cidadania); integração do serviço, família e comunidade; e grupo de família. 
Sendo assim, no que se refere às ações de desinstitucionalização, a primeira estratégia apontada trata da abertura ou fomento a participação das famílias no serviço. Essa questão surge no depoimento que se segue:

Então trazer a família mais presente, disponibilizar os nossos telefones né, e a vinda dessa família quando ela sente alguma dificuldade acho que é umas das coisas que tem aproximado bastante a família e serviço (EP1).

Diante do exposto, pode-se entender que, por meio dessa abertura, o CAPS busca cumprir seu papel ao tentar tornar possível a criação de vínculo entre familiares e profissionais. Sabe-se que estas relações dependem de diversos fatores, mas que de forma geral, são potencializadas quando se busca ser mais próximo e promovendo a confiança dos familiares para com o serviço, propiciando assim, a inserção das famílias nas práticas de cuidados do CAPS.

Mediante a confiança, o vínculo constitui-se, estabelecendo-se como um recurso terapêutico, uma vez que, aproxima a família, o usuário e a equipe, favorecendo a comunicação e a troca de subsídios inerentes ao viver e conviver com uma pessoa em sofrimento mental (RIBEIRO; COIMBRA; BORGES, 2012, p. 378).

Sendo que a lógica da Reforma Psiquiátrica é de promover o cuidar em liberdade antes de qualquer coisa, o CAPS é um meio de oferecer subsídios para esse cuidar. Essa referência de atenção propõe a redução de internações em leitos psiquiátricos tradicionais a partir da geração de um olhar e práticas verdadeiramente substitutivas ao modelo manicomial na atenção à saúde mental (COSTA et al., 2014). Neste sentido, o familiar reflete no seu depoimento o papel do CAPS na redução das internações do usuário:

[...] Até mesmo os medicamentos foi mudado e ele gosta de vim, então isso já é um ponto bom. [...] Mas o CAPS tá aju- 
dando bastante, porque assim ó, [...] se eu não procurasse o CAPS pra me ajudar, tinha que internar ele, porque pela agressividade dele eu não ia conseguir. Porque eu também já fui depressiva, então ia se complicando né. Mas hoje graças a Deus a gente tá dando uma animada boa mesmo com isso né, porque na verdade o CAPS ajuda e ajuda bastante, porque a gente precisa (EF2).

Um dos profissionais corrobora com essa questão ressaltando:

Porque antes a forma de tratamento estava vinculada: o paciente toma medicação, paciente fica internado, paciente fica isolado da sociedade, a institucionalização e o CAPS vem num movimento totalmente contrário, de que embora eu tenha um transtorno, mas que eu faço parte de um meio social, eu posso participar, estar em todos os equipamentos sociais da rede de serviço [...] então eles têm um apoio bem maior e também porque, assim, quem tá no CAPS interna menos né, então a necessidade de internação reduziu bastante. Então o CAPS oferece um serviço bem completo assim. Então as famílias, elas falam isso pra gente, é um feedback que a gente tem deles (EP2).

Nessa perspectiva, o propósito dos serviços substitutivos é de transformar a internação hospitalar como a última medida a ser adotada ao trabalhar com foco na promoção, prevenção e reabilitação em saúde mental. Identificou-se que o CAPS I de Lauro Müller tem buscado prestar apoio às famílias das pessoas com sofrimento psíquico, com a finalidade de ampará-la no enfrentamento das necessidades diárias, reduzindo as internações psiquiátricas.

O exposto vai ao encontro do expresso pela literatura examinada, a qual discorre que a inserção e a expansão dos serviços de saúde de base comunitária permitem a ruptura com o ciclo das internações, uma vez que nesses dispositivos são integradas ações que contribuem para que o sujei- 
to desenvolva autonomia, assim como sua capacidade de contratualidade (BORBA et al., 2011).

Compreendendo a autonomia como "capacidade de um indivíduo gerar normas, ordens para a sua vida, conforme as diversas situações que enfrente" (PITTA, 2016), foram evidenciadas também ações de promoção do desenvolvimento da autonomia e reinserção social configurando-se como atividades de atenção não apenas para o usuário, mas à sua família. Isso se mostra presente na narrativa subsequente:

Então a reinserção social, que é um dos serviços que a gente efetiva dentro do CAPS, ela se dá através da família, porque se eu tenho uma familia que ela opta em colocar esse paciente, em deixar esse paciente escondido, que ele não pode sair de casa, de que ele não pode ter contato com a sociedade, participar dos serviços, ter uma vida social e comunitária e até familiar, participar, por exemplo, de festas, datas pontuais comemorativas, então 'ah, ele não tem que tá nesse meio' [...]. Então justamente nosso papel com a familia é da gente trabalhar. Um outro ponto importante é a gente trabalhar o empoderamento e a autonomia do paciente, porque por mais que ele tenha um transtorno, eu tenho que desenvolver algumas potencialidades e habilidades desse paciente, pra ele conseguir ter uma autonomia, então, por exemplo, existem pacientes que conseguem administrar sua medicação tranquilamente, existem pacientes que não. Um caso, o paciente tem uma dificuldade de se vestir, a família vai lá e veste, então a gente sempre trabalha com a família esse sentido de que eu preciso emancipar essa autonomia e ver o potencial, aí eu vou auxiliar naquilo que ele apresenta uma certa dificuldade, e não fazer por ele né. Porque quando eu faço por ele, eu incapacito, e o objetivo do nosso serviço é mostrar que ele não é um paciente incapacitado (EP1).

Assim, os resultados encontrados vão ao encontro dos achados por Schrank (2006, p. 90), os quais identificaram que: 
Convocar a família para assumir a responsabilidade do cuidado do usuário em conjunto com a equipe, exige mais do que um redirecionamento das práticas, exige comprometimento e responsabilidade para a construção de um cuidado que é coletivo desses atores em promover e manter a autonomia do usuário, reconquistar sua cidadania e seu espaço na sociedade, construindo uma responsabilização e um cuidado coletivo.

No que diz respeito a reinserção social de forma mais específica, outro aspecto relevante, é que no CAPS em estudo algumas iniciativas são tomadas para aproximar a família do serviço e para inserir os usuários em seu meio social. Destacando-se, assim, a participação em alguns eventos dentro e fora do serviço, o que é explicitado nos relatos:

[...] eu participei foi dia das Mães esse ano, assim ela botou DVD pra gente ver [...] eles participava junto com a gente também, foi uma coisa muito maravilhosa, foi um encontro de família e a gente participou com eles todos juntos [usuários] e daí foi um encontro que a gente, por exemplo, a gente vem reunião só nossa, os familiares, e então assim, o convivio de conhecer todos eles juntos, assim, vem gente de Treviso, foi um convívio que a gente conheceu, ali a gente viu e conheceu pessoas que ela [usuária] falava e a gente não conhecia. Então foi bem importante. [...] uma coisa bem boa que ela fez, que uniu a família tudo junto, bem maravilhoso (EF1).

O objetivo do CAPS não é encapsular, a gente ensina todo o trabalho com a rede, o trabalho social, e a gente trabalha muito o empoderamento, a interação social, a gente otimiza muito os movimentos de participação na comunidade, por exemplo, no desfile cívico, a gente vai trabalhar uma temática de mostrar que eles estão tão bem de participar de uma atividade comunitária como qualquer outro cidadão, então a gente trabalha esse empoderamento e traz também a família [...] (EP1). 
As atividades comemorativas como Dia das Mães, desfile cívico, festa junina são eventos de suporte afetivo do CAPS em estudo, que contribuem para a integração família, usuário, equipe e comunidade, assim como são considerados instrumentos facilitadores para um trabalho conjunto da família.

Conforme os familiares, um aspecto notável desta equipe, refere-se ao modelo de relação que esses profissionais priorizam nos encontros com os usuários e familiares. Essas relações dispõem de características como respeito, escuta e engajamento, manifestando a importância na qualidade dos encontros e das interações entre os sujeitos sociais. Nesse sentido, "as relações que se estabelecem dentro do CAPS, tanto entre usuários como entre os familiares, representam uma grande possibilidade de suporte afetivo para todas as pessoas envolvidas" (SANTIN; KLAFKE, 2011, p. 156).

Assim, a prática dos profissionais do serviço também é vista pelos familiares como um "dom", ou seja, que perpassa a relação de trabalho, compreendendo que a relação de cuidado e de entrega vão para além da técnica. Estas questões são observadas nas narrativas que seguem:

Com nós também é maravilha, não tem nem o que comentar, eles são maravilhosos, todas elas assim, tanto motorista, todos bem atenciosos [...] pra conviver com eles, participar, tem que ter um amor muito grande, porque assim, o domínio [...], como diz, tem que ter fé no serviço que vai frequentar né, porque o dia a dia é uma experiência, o convívio com eles, porque assim, cada dia é uma busca nova né, e é gratificante eles chega assim com coisas nova. Ela (familiar) mesma, meu Deus, ela fica feliz, se entra outros novos assim, ela fica bem contente. Então é assim, ela tem um amor em todos eles né, em todos (EF1).

Eu gosto da maneira que elas (profissionais) são, assim, acolhedoras sabe, algo gostoso. Acho que não precisa melhorar, porque o que elas mostram é amor, é carinho pelos pacientes, pela família né (EF2). 
Nessa ótica, as características da equipe são percebidas pelos familiares de forma que estes reconhecem que o envolvimento perpassa uma dimensão relacional. Os sujeitos sociais estão implicados numa relação mais próxima, onde há escuta, compromisso e respeito. E na visão dos autores "essas características remetem ao entendimento de que as interações humanas se constituem como uma importante estratégia que deve ser explorada no espaço de implementação de cuidado no âmbito da saúde mental" (CAMATTA et al., 2011, p. 4408).

Algumas declarações também demonstram que é no espaço do grupo com os familiares, que se possibilita a "troca" de informações, propiciando uma relação mútua, baseada no diálogo e no partilhar de experiências. Neste sentido, os familiares destacam:

No grupo mensal a gente fica sabendo de tudo, [...] é bastante informado, porque cada dia é uma coisa diferente, porque tem bastante atividade e às vezes tem até coisas novas que a gente não sabe. [...] A gente vem a reunião e a psicóloga sempre explica pra dar o remédio na hora certa, ela explica bem certinho como fazer [...] assim ó, a gente às vezes até fica com dúvidas e elas vão e esclarece como é. Então a gente sai assim, como saber lidar com eles (EF1).

Na verdade, elas passam o que pra gente? Conhecimento sabe, da doença né, do processo que nós estamos lidando [...] como eu devo praticar, com é que eu vou agir sabe, porque assim ó, a maneira que eu tenho aprendido nessas reuniões que eu tenho vindo, o que que acontece [...] tu começa refletir tudo. E quando ela explica, tu te leva no meio de todos, então de cada um tu vai pegando um pouquinho pra melhorar, pra uma mudança em casa e é bom porque tu aprende, tu vai aprendendo, é uma troca de experiência, $e$ isso elas têm bastante, essa experiência pra passar. Que nem eu digo, eu tenho 40 anos, mas na doença do (familiar) eu sou uma criança, não sei quase nada, sei o que ele fazia do passado né, daqui pra frente já é outra coisa. Hoje eu já sei como me relacionar melhor com ele, por mais que 
ele te bota um empecilho e tu não consegue, mas daí tu sabe também que é da doença, que não é fácil (EF2).

Em vista disso, percebe-se que o grupo de família é considerado uma maneira influente de inclusão da família no serviço. Mais do que uma referência positiva, o grupo é visto pelos familiares como uma forma e promover a corresponsabilidade do cuidado. Neste contexto, a palavra "troca" traz uma dimensão de que a pessoa não está lá apenas para receber, mas ela também oferece algo, ou seja, a pessoa sente-se parte daquele processo no qual "eu dou e eu recebo". Assim, exprimindo que a mesma pessoa não vai ao grupo apenas para aprender, ela também pode ensinar, porque tem conhecimento a partir da vivência empírica.

Dessa forma, um grupo de familiares pode funcionar como um espaço de acolhimento das experiências de vida dos seus participantes. O estímulo às trocas de experiências tem se revelado uma importante ferramenta para ampliar a capacidade de lidar com os problemas, assim como tem permitido que um familiar possa se abrir para o discurso do seu companheiro (MELMAN, 2008 apud TELES; BOMFIM; QUEIROZ, 2016, p. 4).

É possível perceber que o grupo de familiares é visto pelos sujeitos do estudo como uma estratégia de inserção da família no desenvolvimento do Projeto Terapêutico Singular (PTS). Neste sentido, é no grupo que o familiar acompanha o andamento do tratamento do usuário, avaliando seu progresso e participando do processo terapêutico. Assim sendo, pode-se dizer que o grupo então informa, esclarece, mas, além disso, é um espaço de troca, de significados para as experiências e, inclusive, de organização do projeto terapêutico.

A construção de um projeto terapêutico singular deve ser compreendida como estratégia que, em sua proposição e 
desenvolvimento, envolve a pessoa com transtorno mental, seus familiares e a rede social, num processo contínuo, integrado e negociado de ações voltadas à satisfação de necessidades e produção de autonomia, protagonismo, inclusão social (BOCCARDO et al., 2011, p. 87).

Pode-se deduzir que o grupo de família é o local do qual se centraliza todas as outras estratégias, incluindo o PTS. Neste sentido, verifica-se que há conversas com as famílias sobre a possibilidade de o usuário vir mais vezes por semana, por exemplo, entre outros assuntos que envolvem a reabilitação psicossocial dos usuários.

O grupo de família é fundamental, de forma que os profissionais possam entender a dinâmica familiar e apontar possibilidades de intervenções no contexto da família, salientando a necessidade de integração usuário, família e serviço. Por longos anos, o indivíduo com transtorno mental foi separado do convívio com a família e a sociedade, porém o modo de reabilitação psicossocial reintegra o sujeito com sofrimento psíquico em seu contexto familiar e social (FACURY, 2010).

Sendo assim, considera-se o grupo de família uma estratégia terapêutica indispensável para as ações de desinstitucionalização no CAPS I de Lauro Müller, promovendo a preparação dos familiares para lidar com o contexto vivenciado por estes, bem como proporcionando um alicerce seguro para o usuário ao longo do seu tratamento.

Nesse sentido, para Saraceno (2016), a reabilitação psicossocial é apontada como uma indispensabilidade e obrigação ética e deve incumbir aos profissionais que dispõem de uma abordagem ética no campo da saúde mental.

É importante destacar que os familiares referenciam o serviço do CAPS de maneira bastante positiva, mostrando a relevância do CAPS para os usuários e suas famílias. Algumas falas ilustram essa afirmação:

[...] sinto bem acolhida, é muito bom, é bem gratificante, coisa boa foi vim o CAPS para Lauro Müller, nossa... Num 
momento assim, todo mundo dizia 'nossa quem vai no CAPS é louco', mas só quem diz não sabe o trabalho que é aqui, só participando pra gente ver como é né (EF1).

[...] eu acho bem bom o que elas estão fazendo tá, muito bom mesmo, um trabalho incrivel, porque quando elas falaram assim [...] 60 pessoas sabe, 60 pessoas com saúde já te dão trabalho, agora tu imagina com problemas mentais, é uma responsabilidade muito grande [...] (EF2).

Nas falas dos familiares é possível identificar a satisfação de ambos com a existência dos serviços substitutivos do tipo CAPS. Para Ribeiro, Coimbra e Borges (2012), o sentimento dos familiares no que se refere à satisfação perante o suporte obtido dos profissionais de saúde, possibilita "a esperança de uma vida mais dirigida às reais necessidades do familiar em sofrimento mental. Assim, quanto mais conectados estiverem os profissionais e a família deste, mais próximos todos estarão de um convívio saudável” (p. 383).

Por conseguinte, é importante destacar que a equipe técnica mínima para atuação no CAPS I, conforme a portaria n. 336/02, deve ser composta por 1 médico com formação em saúde mental; 1 enfermeiro; 3 profissionais de nível superior, podendo ser: psicólogo, assistente social, terapeuta ocupacional, pedagogo ou outro profissional necessário ao projeto terapêutico; e 4 profissionais de nível médio: técnico e/ou auxiliar de enfermagem, técnico administrativo, técnico educacional e artesão (BRASIL, 2002). No entanto, a equipe multiprofissional do CAPS I de Lauro Müller é composta atualmente por 1 psiquiatra, 1 enfermeira, 1 assistente social e 2 psicólogos. Sendo que médico não consegue participar das reuniões ou grupo. A equipe tem realizado as atividades em condição de precarização do trabalho, com falta de profissionais que componham a equipe mínima para CAPS do tipo I. Além disso, verificou-se a falta de recursos básicos para seu funcionamento como estrutura física e transporte. Na fala de um dos profissionais verificam-se estas questões: 
Uma coisa bem importante que a gente observa aqui é que se nós deixarmos eles querem vir todos os dias, ai é uma coisa que às vezes nos limita, porque a gente tem a questão de espaço físico, a questão de transporte e a questão de capacidade técnica mesmo né, que é uma coisa bem importante que a gente tem observado (EP1).

Nesse sentido, observou-se que a equipe oferece uma diversidade de ações quanto ao apoio às famílias e atendimento aos usuários. Contudo, as dificuldades percebidas estão no sucateamento do serviço, na falta de investimentos na área da atenção em saúde mental, na insuficiência de equipe e nas dificuldades que os familiares enfrentam para acessar o CAPS.

No que diz respeito aos principais aspectos de mudaram no atendimento no CAPS, os profissionais apontam principalmente para a desmistificação da "loucura", elucidado na seguinte fala:

Eu acredito que o CAPS contribuiu muito para a desmistificação da "doença" mental né, ele diminuiu bastante o preconceito, hoje nós temos aqui pessoas de diversas classes sociais, pessoas assim que não se esperava, a sociedade não esperava que frequentassem o CAPS né, mas frequenta, então acho que o CAPS foi um grande avanço nesse ponto (EP2).

O trabalho do CAPS buscando a inserção da família é essencial e indispensável, uma vez que nessa parceria a família torna-se protagonista, bem como ela precisa de melhores cuidados.

Face ao exposto, pode-se entender que os CAPS são lugares de desenvolvimento de ações em saúde mental e que estes devem possibilitar esta prática. Consequentemente, compreender essas práticas mostra-se fundamental para a concretização e seguimento dos princípios da Reforma Psiquiátrica brasileira. 
Com os avanços da Reforma Psiquiátrica brasileira, muitas transformações vêm acontecendo no âmbito da saúde mental, sendo a maior conquista o processo de desinstitucionalização da pessoa com sofrimento psíquico, bem como a implementação de serviços substitutivos, como o CAPS (SANTIN; KLAFKE, 2011).

Dessa forma, a família assume um importante papel no que se refere à reabilitação psicossocial do seu familiar, sendo, assim, corresponsável pelos cuidados a ele. Nesse sentido, é imprescindível que o CAPS esteja preparado para acolher as demandas que surgem do meio familiar, o qual é visto como peça fundamental no cuidado em saúde mental.

Por meio desta investigação foi possível responder à questão central deste estudo a respeito de como são acompanhadas as famílias de pessoas com sofrimento psíquico que frequentam o CAPS I de Lauro Müller, à luz da proposta da Reforma Psiquiátrica.

Dentre as estratégias identificadas, podem ser citadas: a existência do CAPS, o atendimento individual, o acolhimento, a visita domiciliar, a busca ativa e o grupo de família. Entretanto, o grupo de família foi considerado o principal apoio no que se compete às ações de cuidado direcionadas para os familiares.

A experiência do grupo de família se dá em um contexto em que, para os participantes da pesquisa, representa uma valiosa ferramenta capaz de potencializar o cuidado aos familiares, fomentando a troca de saberes e experiências entre familiares e profissionais, bem como auxilia em seus anseios e os prepara para a convivência com o sujeito em sofrimento psíquico.

As famílias de usuários do CAPS I de Lauro Müller são acompanhadas de forma que sejam reconhecidas como colaboradoras nos cuidados da pessoa com sofrimento psíquico, potencializando a reabilitação psicossocial. E, numa análise no âmbito da política de saúde mental e da Reforma Psiquiátrica, que propõe que o CAPS seja um apoiador às famílias, o mesmo tem a intenção de colaborar com esse apoio; porém, demonstra algumas limitações, dentre as 
quais se pode destacar a falta de profissionais para compor a equipe mínima e o sucateamento do serviço (falta de materiais e transporte). Diante disso, vale salientar que é de extrema importância o interesse da gestão no que diz respeito às políticas de saúde mental.

Ressalta-se, contudo, que acompanhar e oferecer suporte apropriado às famílias mostra-se imprescindível para a efetivação e perpetuidade dos princípios da Reforma Psiquiátrica, sobretudo, no que diz respeito ao resgate da cidadania do sujeito com sofrimento psíquico.

Portanto, apesar dos esforços para o cuidado com a família, se percebe a importância de se estruturar melhor o CAPS com uma equipe completa, transporte apropriado ao serviço, para que esse dispositivo possa assumir de maneira mais qualificada o seu papel de apoio às famílias, e não de um serviço que espere o apoio das famílias.

\section{REFERÊNCIAS}

ALMEIDA, Marcelo Machado de. Cuidadores de pacientes com esquizofrenia: a sobrecarga e a atenção em saúde. 2009. 54 f. Dissertação (Mestrado) Programa de Pós-Graduação em Ciências da Saúde, Fundação Oswaldo Cruz do Centro de Pesquisas René Rachou, Belo Horizonte, 2009.

AMARANTE, Paulo. Loucos pela vida: a trajetória da reforma psiquiátrica no Brasil. 2. ed. Rio de Janeiro: Fiocruz, 2001. 132 p.

. O homem e a serpente: outras histórias para a loucura e a psiquiatria. 20. ed. Rio de Janeiro: Fiocruz, 2003. 142 p.

BOCCARDO, Andreia Cristina S. et al. O projeto terapêutico singular como estratégia de organização do cuidado nos serviços de saúde mental. Rev Ter Ocup. Univ. São Paulo, v. 22, n. 1, p. 85-92, jan./abr., 2011.

BORBA, Letícia de Oliveira et al. A família e o portador de transtorno mental: dinâmica e sua relação familiar. Rev Esc Enferm. USP, São Paulo, v. 45, n. 2, p. 442-449, 2011. 
- Assistência em saúde mental sustentada no modelo psicossocial: narrativas de familiares e pessoas com transtorno mental. Rev Esc Enferm. USP, São Paulo, v. 46, n. 6, p. 1.406-1.414, 2012.

BRASIL. Lei n. 10.216, de 6 de abril de 2001. Dispõe sobre a proteção e os direitos das pessoas portadoras de transtornos mentais e redireciona o modelo assistencial em saúde mental, Brasília, 2001.

. Portaria n. 336, de 19 de fevereiro de 2002. Dispõe sobre os Centros de Atenção Psicossocial - CAPS, para atendimento público em saúde mental, isto é, pacientes com transtornos mentais severos e persistentes em sua área territorial, em regime de tratamento intensivo, semi-intensivo e não-intensivo, Brasília, 2002.

CAMATTA, Marcio Wagner et al. Avaliação de um Centro de Atenção Psicossocial: o olhar da família. Ciência e saúde coletiva, Porto Alegre, v. 16, n. 11, p. 4405-4414, 2011.

COSTA, Giliana Martins da et al. A importância da família nas práticas de cuidado no campo da saúde mental. Cadernos ESP, Ceará, v. 8, n. 1, p. 41-57, 2014.

FACURY, Ana Paula Maia. A saúde mental na estratégia de saúde da família Dr. Roberto Andrés - entre Rios de Minas. 2010. 47f. Monografia (Especialização em Atenção Básica em Saúde da Família) - Universidade Federal de Minas Gerais, 2010.

GOMES, Romeu. A análise de dados em pesquisa qualitativa. In: MINAYO, Maria Cecília de Souza. Pesquisa social: teoria, método e criatividade. 23. ed. Petrópolis: Vozes, 2004. p. 67-80.

INSTITUTO BRASILEIRO DE GEOGRAFIA E ESTATÍSTICA (IBGE). Brasil, 2017. Disponível em: <https://cidades.ibge.gov.br/brasil/sc/lauro-muller/ panoramaem>. Acesso em: 7 abr. 2018. 
LEMKE, Ruben Artur; SILVA, Rosane Azevedo Neves da. A busca ativa como princípio político das práticas de cuidado no território. Estudos e pesquisas em psicologia, Rio de Janeiro, v. 10, n. 1, p. 281-295, 2010.

MICHEL, Maria Helena. Metodologia e pesquisa científica em ciências sociais: um guia prático para acompanhamento da disciplina e elaboração de trabalhos monográficos. 3. ed. São Paulo: Atlas, 2015. 284 p.

MIELKE, Fernanda Barreto et al. A inclusão da família na atenção psicossocial: uma reflexão. Revista eletrônica de enfermagem. v. 12, n. 4, p. 761-5, out./dez. 2010.

MINAYO, Maria Cecília de Souza. O desafio do conhecimento: pesquisa qualitativa em saúde. 11. ed. São Paulo: Hucitec, 2008. 407 p.

PITTA, Ana Maria Fernandes. O que é reabilitação psicossocial no Brasil, hoje? In: (Org.). Reabilitação Psicossocial no Brasil. 4. ed. São Paulo: Hucitec, 2016. p. 27-36.

RIBEIRO, Juliane P.; COIMBRA, Valéria Cristina; BORGES, Anelise M. Grupo de familiares de um centro de atenção psicossocial: experiências de seus usuários. Rev de Enfermagem da UFSM, Santa Maria-RS, v. 2, n. 2, p. 375-385, 2012.

ROTELLI,Franco;LEONARDIS,Otade;MAURI,Diana.Desinstitucionalização, uma outra via: a Reforma Psiquiátrica italiana no contexto da Europa Ocidental e dos "países avançados". In: . Desinstitucionalização. 2. ed. São Paulo: Hucitec, 2001. p. 17-59.

SANTIN, Gisele; KLAFKE, Teresinha Eduardes. A família e o cuidado em saúde mental. [S.1.], Santa Cruz do Sul, n. 34, p. 146-160, jan./jul., 2011.

SARACENO, Benedetto. Reabilitação psicossocial: uma estratégia para a passagem do milênio. In: PITTA, Ana Maria Fernandes. Reabilitação Psicossocial no Brasil. 4. ed. São Paulo: Hucitec, 2016. p. 19-26. 
SCHRANK, Guisela. O centro de atenção psicossocial e a inserção da família. 2006. 113 f. Dissertação (Mestrado) - Universidade Federal do Rio Grande do Sul. Escola de enfermagem, Porto Alegre, 2006.

TELES, Mayara Soares Brito; BOMFIM, Jamile Melo; QUEIROZ, Ana Helena Araújo Bomfim. O trabalho com grupos de família no CAPS: reflexões a partir da experiência de estágio. Cadernos de Graduação, Sobral-CE, v. 2, n. 4, p. 1-17, 2016.

TOMASI, Neusi Garcia Segura; YAMAMOTO, Rita Miako. Metodologia da pesquisa em saúde: fundamentos essenciais. Curitiba: As autoras, 1999. 98 p. ZIMERMAN, David E. Fundamentos básicos das grupoterapias. 2. ed. Porto Alegre: Artmed, 2000. 244 p. 